Characterization and monosaccharide content of pectin from Nephrolepis biserrata leaves

Halifah Pagarra, Roshanida A. Rahman, Rachmawaty, Hartati, and Andi Asmawati Azis

Citation: AIP Conference Proceedings 2030, 020178 (2018); doi: 10.1063/1.5066819

View online: https://doi.org/10.1063/1.5066819

View Table of Contents: http://aip.scitation.org/toc/apc/2030/1

Published by the American Institute of Physics

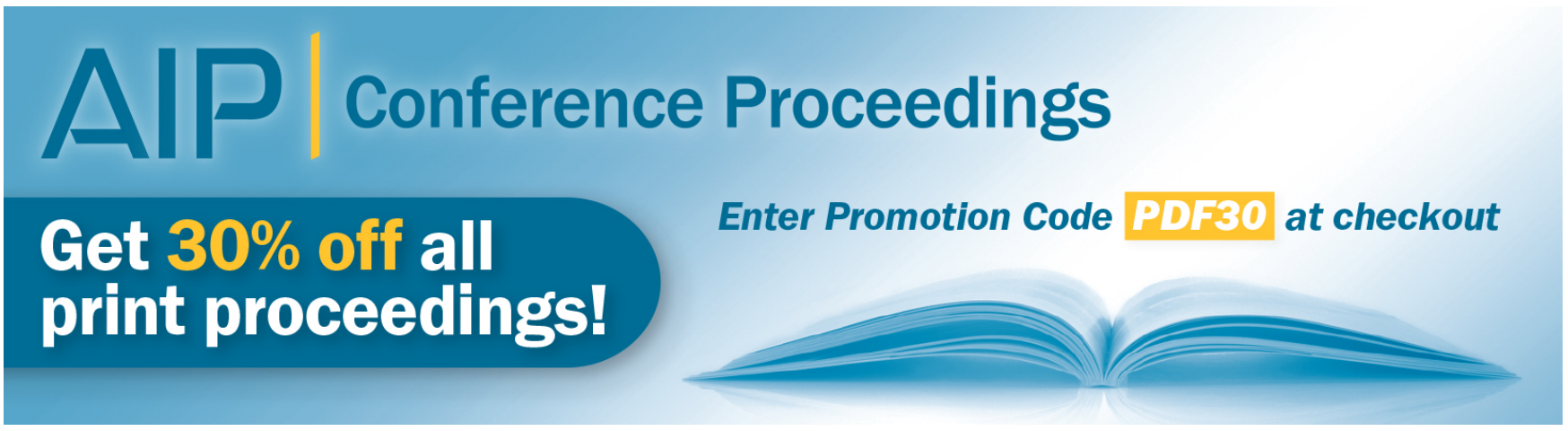




\title{
Characterization and Monosaccharide Content of Pectin from Nephrolepis biserrata Leaves
}

\author{
Halifah Pagarra ${ }^{1, \mathrm{a})}$, Roshanida A. Rahman ${ }^{2, \mathrm{~b})}$, Rachmawaty ${ }^{3, \mathrm{c})}$, Hartati $^{4, \mathrm{~d})}$ and \\ Andi Asmawati Azis ${ }^{5, e)}$ \\ 1,3,4,5 Department of Biology, Faculty of Mathematics and Natural Sciences Universitas Negeri Makassar \\ Indonesia \\ ${ }^{2}$ Department of Bioprocess, Faculty of Chemistry and Energy Universiti Teknologi Malaysia, Skudai Johor \\ Bahru Malaysia \\ a)corresponding author: halifah.pagarra@unm.ac.id \\ b) roshanida@cheme.utm.my \\ c)rachmawaty@unm.ac.id \\ d)hartati@unm.ac.id \\ e) asma.azis@gmail.com
}

\begin{abstract}
Pectins are additive compounds serving as gelling agents. Until now, demands for pectins most solely come from imports, whereas it is known that pectins are available from all around. One of major sources of pectin is from the leaves of Nephrolepis biserrata. The purpose of the study is to settle for characteristics and contents of pectin monosaccharide from Nephrolepis biserrata. The leaves of Nephrolepis biserrata were extracted by reflux using $0.5 \mathrm{~N}$ sulphuric acid, then precipitated twice along with $95 \%$ ethanol and then dried. Characteristics of pectin in Nephrolepis biserrata were based on $1250 \mathrm{~g} / \mathrm{mol}$ of equivalent weight, $7.07 \%$ of methoxyl content, $48.82 \%$ of galacturonic acid content, and esterification degree of $84.16 \%$. Pectin of Nephrolepis biserrata leaves is classified as methoxyl-rich pectins. Moderate sugar monosaccharide contents $(\mathrm{g} / \mathrm{L})$ of Nephrolepis biserrata leaves were analyzed using high performance liquid chromatography (HPLC), those are 0.277 arabinose, 0.161 ramnose, 0.035 mannose, 0.011 galactose, and 0.002 xylose. Monosaccharide content of pectin in Nephrolepis biserrata leaves is classified as lower class compared to commercially-available citrus monosaccharide pectin.
\end{abstract}

\section{INTRODUCTION}

It is well-known that pectin has a role as a polysaccharide structure in the main cell walls and middle lamellartall plants which contributes to the structural strength of a plant $[1,2,3]$ and also to various cell functions including defense and cell adhesion [4]. Its components in original form should be found in cell wall and possibly in between polysaccharide and other proteins to form insoluble protopectin. Insoluble protopectin will then serve to maintain the shape of cell wall. However, on mature phase, naturally pectin will be changed by another enzyme in a fruit. Pectin's compund, $\alpha$-D-galacturonic acid (galacturonan) will merge with $\alpha-1,4$-glycocidic chain to form the spine of homogalacturonan consisting of ramnose, arabinose, galactose, and xylose as side chains. Galacturonic units in a plant's cell structure would undergo esterification, forming methanol, approximately $60-70 \%$ [5]. Pectins made were dependant on the condition when extractions were made, such as temperature, time needed, $\mathrm{pH}$, and extraction solvent [6]. Before extractions were started, alcohol soluble residuals would then be prepared to separate low molecular weight compounds, including free galacturonic acid [7]. Based on degree of esterification (DE), pectins are divided into two: high pectin methoxyl (DE $>50 \%)$ and low pectin methoxyl $(\mathrm{DE}<50 \%)$ [8].

Mostly, pectin should reach $0,5-4,0 \%$ out of whole fresh source. Fresh, extracted juice should be rich in insoluble particles which mostly were of pectin. Traditionally, commercial pectin sources come from orange skin. Orange skin were of top choice when it comes to pectin extraction because of its high content of pectin and fine color features. But now, sources of pectin also includes common beets and sunflowers. Pectins harvested from different sources also gave significantly different results [9].

Green Design and Manufacture: Advanced and Emerging Applications AIP Conf. Proc. 2030, 020178-1-020178-5; https://doi.org/10.1063/1.5066819 Published by AIP Publishing. 978-0-7354-1752-6/\$30.00 
The purpose of the study were (i) to characterize pectin from Nephrolepis biserrata leaves, and (ii) to analyze pectin monosaccharide content using HPLC based on previous studies regarding pectin extraction in optimal environment on Response Surface Methodology (RSM) method [10].

\section{EXPERIMENT}

The study was done in Laboratorium Biologi Terapan, Jurusan Teknik Bioproses UTM. Characterization of pectin and analysis of pectin monosaccharide content in Nephrolepis biserrata leaves based on optimal extraction environment using RSM method which was on $\mathrm{pH} 1,5$ in 76.32 minutes of extraction time, along in $100^{\circ} \mathrm{C}$ on $8.16 \%$ of pectin weight [10]. Characterization of extracted pectins from Nephrolepis biserrata leaves were analyzed using characterization methods which were equivalent weight of methoxyl, galacturonic acid content, degree of esterification $[11 ; 12]$ and analysis of monosaccharide content.

\section{Equivalent Weight}

On determining the methoxyl content, AUA content, and equivalent weight, measures by [13] and [14] were followed. Equivalent weight was used to calculate anhidrouronic acid (AUA) content and degree of esterification. Equivalent weight was defined by means of weighing down $0,5 \mathrm{~g}$ of pectin in $250 \mathrm{~mL}$ conical flask, and moisted with $5 \mathrm{~mL}$ of ethanol. A gram of sodium chloride would then be added for more incisive endpoint. Carbondioxidefree distilled water $(100 \mathrm{~mL})$ and six drops of phenol red indicator were then added. The mixture was then stirred until it reached homogenity. Titration was then slowly performed (to avoid the possibility of deesterification) using standard $0,1 \mathrm{~N}$ of $\mathrm{NaOH}$ until the red indicator turned pink (ph 7,5) and lasted 30 seconds at most. Neutralizing solvent was then used to determin methoxyl content. The equation below was used to calculate the equivalent weight:

$$
\text { Equivalent weight }=\frac{\text { Pectin weight } \times 1000 \mathrm{mg}}{\mathrm{ml} \mathrm{NaOH} \times \mathrm{N} \mathrm{NaOH}}
$$

\section{Methoxyl Content Analysis}

In determining the content of methoxyl (MeO), $25 \mathrm{~mL}$ of $0,25 \mathrm{~N} \mathrm{NaOH}$ was added to titration solvent, shaken, and left for 30 minutes in room temperature in stopper flask. And, $25 \mathrm{~mL}$ of $0,25 \mathrm{~N} \mathrm{HCl}$ was then added and titrated until the same previous endpoint. The following equation would then be used to determine the methoxyl content:

$$
\% \mathrm{MeO}=\frac{\text { ml titrated } \mathrm{NaOH} \times 31 \times 100}{\text { Pectin weight }(\mathrm{mg})}
$$

where 31 indicates group of methoxyl molecular weight.

\section{Anhydrouronic Acid Analysis (AUA)}

Using equivalent weight and methoxyl content value, AUA content would then be determined using the following equation:

$$
\% A U A=\frac{176 \times 100}{\mathrm{Z}}
$$

where 176 is the molecular weight for AUA and $\mathrm{Z}$ defines as sample weight (mg) to $\mathrm{NaOH}$ milliequivalent ( $\mu$ eq), which is $\mathrm{ml}$ amount of $\mathrm{NaOH}$ from equivalent weight definition and methoxyl content as defined below:

$$
Z=\frac{\text { Pectin weight }(\mathrm{mg})}{\mu \mathrm{eq}(\text { Equivalent weight }+\% \mathrm{MeO})}
$$

\section{Degree of Esterification (DE)}

Degree of Esterification in pectin was defined as follows:

$$
\% D E=\frac{\% M e O \times 176 \times 100}{\% A U A \times 31}
$$




\section{Analysis of Pectin Monosaccharide Content in Nephrolepis biserrata leaves}

Analysis of monosaccharide (Arabinose, Ramnose, Mannose, Galactose, and Xylose) from pectin in Nephrolepis biserrata was done by using HPLC Agilent 1260 system. Analysis column used was Aminex HPX-87H, $200 \mathrm{x}$ $7,8 \mathrm{~mm}$. Elusion was done on $0,7 \mathrm{~mL} /$ minute flow rate using RI detector [15].

\section{RESULTS AND DISCUSSION}

Characterization of pectin in Nephrolepis biserrata leaves was initiated on pectins extracted during optimal condition and environment are obtainable. The characterization itself was of the utmost important to determine which of the pectins were better than those extracted out of other sources, not to mention those commercially available on markets.

\section{Equivalent Weight}

Equivalent weight of pectin extracted from Nephrolepis biserrata leaves was $1250 \mathrm{~g} / \mathrm{mol}$. A number of previous studies on pectin extraction have stated that their outcomes were ranging from 476-1209 g/mol $[11 ; 16]$. [16] found that the weight of pectin-higher value of weight equals to better gel-forming effect. And, that the commercial weight of orange-derived pectin was equal to that of orange extraction, namely $893 \mathrm{~g} / \mathrm{mol}$ [17]. This means, measured weight of pectin obtained from this study turned out to be much higher than that of equivalent weight of pectin derived from commercial citrus.

\section{Methoxyl Content}

Methoxyl content in pectin was defined as mol amount of methyl alcohol in $100 \mathrm{~mL}$ of galacturonic acid. The content of methoxyl in pectin is important to control the strength in gel, time management, sensitivity to metallic ions, and to identify the feature of pectin solvent and pectin gel structure [18]. Pectin would be classified as high in methoxyl of its content was equal to $7 \%$ or higher. If methoxyl content was less than $7 \%$, then it would be classified as low in methoxyl [19]. Methoxyl content of pectin extract from Nephrolepis biserrata leaves was $7.07 \%$. Based on methoxyl content, pectin obtained from this study should be classified as high in methoxyl, thus the value was exceeding $7 \%$.

The content of AUA (anhydrouronic acid) derived from pectin extract in this study was $48.82 \%$. Many previous studies have found that their outcomes of AUA content were 8.10-73\% [11,20,21]. [16] reported that AUA derived from orange skin was $10 \%$ and $19 \%$. While AUA derived from commercial citrus was $74.29 \%$ [17] . AUA content obtained in this study was lower in value, namely $25.47 \%$ difference, compared to that of commercial citrus pectin. However, to keep the purity of extracted pectin, it was recommended to keep AUA of no more than $65 \%$ [22].

\section{Degree of Esterification}

Classification of pectin from Nephrolepis biserrata leaves was $84.16 \%$. Pectin obtained in this study therefore should be categorized as high in methoxyl pectin owing to its percentage content of higher than $50 \%$. [13] stated that pectin with esterification degree $>50 \%$ was known as high methoxyl pectin whereas pectin with esterification degree $<50 \%$ was known as low methoxyl pectin. [16] reported that the degree of esterification in lemon-derived pectin was $88.62 \%$, and that derived from commercial orange was $69.48 \%$ [17]. The result of this study is clearly pointing out that the degree of esterification in pectin from Nephrolepis biserrata leaves was much higher than commercial orange pectin.

\section{Pectin Monosaccharide Content in Nephrolepis biserrata leaves}

Monosaccharide contents consist of arabinose, ramnose, mannose, galactose, and xylose from Nephrolepis biserrata leaves. Based on methoxyl content, pectin obtained in this study is classified as high in methoxyl pectin, due to the value exceeded $7 \%$. 


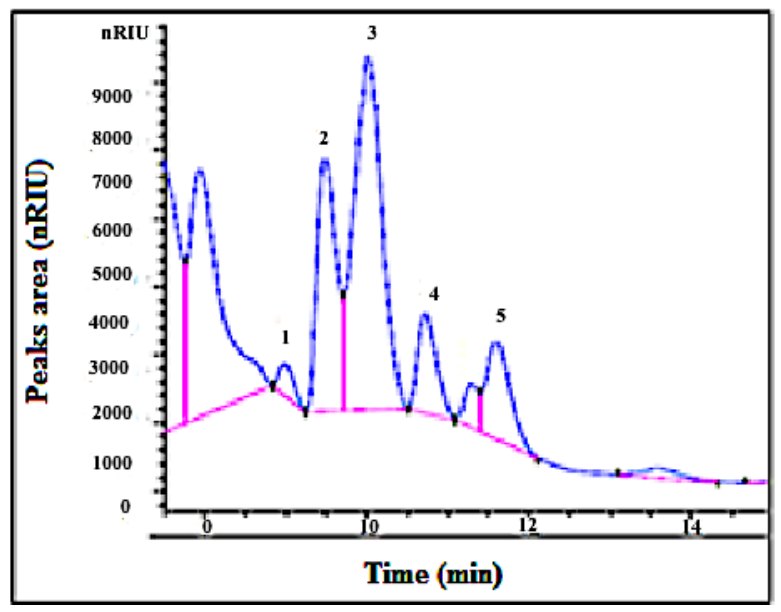

FIGURE 1. Monosaccharide content contained in pectin from Nephrolepis biserrata leaves (1) Xylose, (2) Ramnose, (3) Arabinose, (4) Mannose, (5) Galactose.

Contents of arabinose, ramnose, mannose, galactose, and xylose in pectin from Nephrolepis biserrata leaves. Our study shows that arabinose content $(\mathrm{g} / \mathrm{L})$ was higher than other monosaccharide contents, which was 10.03 minutes (0.277), followed by ramnose on 9.48 minutes $(0.61)$, mannose on 10.718 minutes $(0.035)$, galactose on 11.59 minutes (0.011) and xylose on 8.99 minutes $(0.002)$. In this study, positive linear correlation was found between concentration (ppm) and peaks area of monosaccharide content. This could be the impact of many factors during the extraction of pectin, such as temperature, $\mathrm{pH}$, acid type, and used source of pectin[23,24]. The most important source was based on the maturity of used fruit's skin or fruit, where the maturity itself served as the source of pectin, as the monosaccharide content should be higher $[15,25,26,27]$.

\section{CONCLUSION}

Result of this study and the data analysis showed that characterization of pectin from Nephrolepis biserrata leaves that, equivalent weight and degree of esterification in pectin from Nephrolepis biserrata leaves was higher than that of commercial oranges. AUA content showed lower value than that of commercial citrus. Based on methoxyl content, pectin obtained in this study was classified as high methoxyl pectin, due to its value exceeding $7 \%$. Monosaccharide content of pectin from Nephrolepis biserrata leaves was lower than that of pectin monosaccharide content from commercial citrus.

\section{REFERENCES}

1. Lang, C. and Dornenburg, H. Applied Microbiology and Biotchnology. vol.53, pp. 366-375, (2000)

2. Alimardani-Theuil, P.; Gainvors-Claisse., A. and Duchiron, F. Yeasts. Process Biochemistry. vol.46, pp. 1525 1537, (2011).

3. Gummadi S. N. and Panda T. Process Biochem. vol.38, pp. 987-996, (2003)

4. Mohnen, D.Current Opinion in Plant Biology. vol. 11, pp. 266-277, (2008)

5. Gummadi S. N., Manoj N. and Kumar D. S. Industrial Enzymes. Springer, pp. 99-115, (2007)

6. Yeoh, S., Shi, J. \& Langrish, T.A.G. Desalination. vol.218, pp. 229-237, (2008)

7. Happi, T.E., Ronkart, S.N., Robert, C., Wathelet, B. and Paquot, M. Food Chemistry, 108: 463-471.

8. Mesbahi, G., Jamaliana, J. \& Farahnaky, A. 2005. A comparative study on functional properties of beet and citrus pectins in food systems. Food Hydrocolloids. vol.19, pp. 731-738, (2008)

9. Vibha, B. and Neelam, G. Globelics 8th International Confrence., $1^{\text {st }}-3^{\text {rd }}$ Nopember. University of Malaya. pp. 1-16, (2010)

10. Pagarra, H., Rahman, R.A.,. Illias, R.Md and Ramli, A.N. Applied Mechanics and Materials. vol. 625, pp. 920-923 (2014)

11. Ismail, N.S.M., Ramli, N., Hani, N.M. and Meon, Z. Sains Malaysiana. vol. 41(1), pp. 41-45, (2012) 
12. Pinheiro, E.S.; Silva, I.M.; Gonzaga, L.V.; Amante, E.R.; Teófilo, R.F.; Ferreira, M.M.; Amboni, R.D. Bioresour. Technol. vol. 99, pp. 5561-5566, (2008)

13. Kumar, R.S., Nayagi, Y.A.P.P. and Afandi, A. Research Journal of Agriculture and Forestry Sciences. vol. 1(2), pp. 1-11, (2013)

14. Aina, V.O., Barau, M.M., Mamman, O.A., Zakari, A., Haruna, H., Hauwa, M.S.U. and Baba, Y.A. British Journal of Pharmacology and Toxicology. vol. 3(6), pp. 259-262, (2012)

15. Georgiev, Y., Ognyanov, M., Yanakieva, I., Kussovski, V. And Kratchanova, M. J. BioSci. Biotech. vol. 1(3), pp. 223-233, (2012)

16. Salam M. A., Jahan N., Islam M. A. and Hoque M. M. Journal of Chemical Engineering. vol. 27(2), pp. 25-31, (2012)

17. Castillo-Israel, K.A.T., Baguio, S.F., Diasanta, M.D.B., Lizardo, R.C.M., Dizon, E.I. and Mejico, M.I.F. International Food Research Journal. vol. 22(1), pp. 202-207, (2015)

18. Constenla, D. dan Lozano, J.E. Latin American Applied Research. vol. 33, pp.91-96, . (2003)

19. Goycoolea, F.M., and Cardenas, A. J.PACD. vol. 17: 29, (2003)

20. Abid, H., Hussain, A., Ali, S. and Ali, J. Journal of the Chemical Society of Pakistan. vol. 31, pp. 459461, . (2009)

21. Rehman, Z. and Salariya, A.M. J FOOD SCI 2005. vol. 15(1-2), pp. 21-23, (2005)

22. Food Chemical Codex. IV Monographs. Washington DC: National Academy Press. (1996)

23. Devi, W.E., Shukla, R N Bala, K L., Kumar, , A. Mishra, A A. and Yadav, C. International Journal of Engineering Research and Technology (IJERT). vol. 3(5), pp. 1925-1932, (2014)

24. Chan, S.Y and Choo, W.S. Food Chemistry. vol. 141, pp. 3752-3758, (2013)

25. Yapo, B. M., Robert, C., Etienne, I., Wathelet, B. and Paquot, M. Food Chemistry. vol. 100, pp. 13561364, (2007)

26. Panouille M, Thibault JF, Bonnin E. Journal of Agricultural Food Chemistry. vol. 54, pp. 8926-8935, (2006)

27. Azad., A.K.M., Ali, M.A., Sorifa, Mst., Jiaur, Md.R. and Ahmed, M. Journal of Food and Nutrition Sciences. vol. 2(2), pp. 30-35, (2014) 